\author{
Stefan Grabowski \\ Uniwersytet Łódzki \\ stefgrab@gmail.com
}

\title{
Rola państw członkowskich Commonwealth w budowie Partnerstwa Transpacyficznego
}

Streszczenie: Partnerstwo Transpacyficzne (Trans Pacific Partnership) w stale rozwijającym się świecie współzależności gospodarczych może odgrywać w niedalekiej przyszłości kluczową rolę z powodu potencjału tworzących je państw. Wielkość gospodarek regionu Azji i Pacyfiku, oraz Ameryki Północnej i Południowej, a także dynamika ich wzrostu każe z uwagą przyglądać się ich działaniom integracyjnym podejmowanym na płaszczyźnie zarówno politycznej jak i ekonomicznej. W artykule scharakteryzowana została rola państw członkowskich Commonwealth $\mathrm{w}$ budowie Partnerstwa Transpacyficznego. Od samego początku istnienia ugrupowania integracyjnego, państwa Wspólnoty Narodów znajdowały się w większości i miały decydujący wpływ na podejmowane działania. Dążenie do zwiększania współpracy w zakresie stosunków ekonomicznych, oraz liberalizacja handlu światowego legły u podstaw tworzenia Commonwealth i zostały zapisane w Deklaracji Singapurskiej określającej cele organizacji. Przedmiotem szczególnej analizy w artykule stały się Kanada oraz Australia - trzecia i czwarta największa gospodarka Commonwealth i TPP. Niewykluczone jest też przystąpienie do prac nad tworzącym się układem handlowym kolejnych państw zrzeszonych we Wspólnocie Narodów.

W XXI wieku bardzo ważną rolę w kształtowaniu polityki zagranicznej odgrywają stosunki gospodarcze między państwami. Dążenie do liberalizacji handlu w ramach kolejnych rund negocjacyjnych Światowej Organizacji Handlu (WTO) prowadzi do zawiązywania bilateralnych, oraz multilateralnych porozumień najczęściej o charakterze preferencyjnych stref wolnego handlu. Obecnie trwająca Runda Doha, nazywana również katarską, rozpoczęła się w 2001 roku i ma na celu przede wszystkim wsparcie rozwoju najbiedniejszych państw świata. Pobudzanie rozwoju poprzez handel międzynarodowy stało się absolutnym priorytetem dla światowych przywódców państw. Zdecydowana większość państw według badań prowa- 
dzonych przez WTO uczestniczy w dwu- lub wielostronnych układach handlowych. Brak postępów w bieżących negocjacjach $\mathrm{w}$ ramach WTO spowodował dynamizację rozmów nad projektami ugrupowań integracyjnych. Negocjacje takie mają miejsce głównie wśród państw bliskich sobie geograficznie lub kulturowo.

Integracja ekonomiczna postępuje najczęściej w zakresie geograficznym prowadząc do powstawania regionalnych bloków (unie celne i strefy wolnego handlu), które następnie starają się połączyć więzami preferencyjnych porozumień z innymi podobnymi wielkością ugrupowaniami. W rejonie basenu Pacyfiku można obecnie wyróżnić kilka ugrupowań integracyjnych o różnej dynamice integracji i celach wspólnotowych. Liderem w ekonomicznej integracji regionu są państwa zrzeszone w ASEAN (Stowarzyszenie Narodów Azji Południowo-Wschodniej), które postawiły sobie za cel utworzenie do 2015 roku Wspólnoty Ekonomicznej wzorowanej na Unii Europejskiej (ASEAN Secretariat, 2012: 5). W Azji Wschodniej i Południowo-Wschodniej ścierają się ponadto ze sobą dwie różne koncepcje, co jest również pochodną rywalizacji dwóch największych mocarstw gospodarczych - Stanów Zjednoczonych i Chińskiej Republiki Ludowej. Ogłoszony w ostatnim czasie zwrot amerykańskiej polityki zagranicznej w stronę regionu Azji i Pacyfiku (tzw. pivot to Asia) potwierdza zwiększone zainteresowanie budową nie tylko militarnej prezencji, ale też gospodarczego oddziaływania jedynego supermocarstwa. Popierana przez USA koncepcja Partnerstwa Transpacyficznego (TPP - Trans-Pacific Partnership) skierowana jest do państw położonych po obu stronach Pacyfiku i w założeniu ma składać się właśnie z nich. Regional Comprehensive Economic Partnership (RCEP) koncepcja lansowana głównie przez Pekin, przy poparciu Tokio oraz krajów ASEAN, jest drogą do połączenia kluczowych azjatyckich gospodarek z państwami Oceanii (Hiebert).

W poniższym artykule chciałbym określić i scharakteryzować rolę państw członkowskich Wspólnoty Narodów (Commonwealth) w procesie budowy Partnerstwa Transpacyficznego. Szczególną uwagę chciałbym zwrócić na korzyści, oraz straty jakie z uczestnictwa w porozumieniu mogą odnieść Australia i Kanada - zajmujące odpowiednio trzecie i czwarte miejsce pod względem rozmiaru PKB zarówno wśród gospodarek Commonwealth jak i Partnerstwa Transpacyficznego.

\section{Idea Partnerstwa Transpacyficznego}

Idea połączenia państw $\mathrm{w}$ regionie umową prowadzącą do liberalizacji wymiany handlowej zrodziła się w trakcie spotkań APEC (Asia-Pacific Economic Cooperation). Porozumienie objęło pierwotnie cztery państwa, z których trzy należą do Wspólnoty Narodów - Brunei, Chile, Singapur oraz 
Nową Zelandię. Podpisany 3 czerwca 2005 dokument Trans-Pacific Strategic Economic Partnership Agreement nazywany skrótowo P4 (od 4 państw członkowskich rejonu Pacyfiku) wszedł w życie 28 maja 2006 roku$^{1}$ (Yuan, 2012: 1). W lutym 2008 roku Stany Zjednoczone zdecydowały o przystąpieniu do rozmów z P4, mając na celu przede wszystkim liberalizację przepływu usług finansowych. W listopadzie 2008 roku do negocjacji w sprawie rozszerzenia układu przystąpiły kolejne państwa: Malezja, Australia, Peru oraz Wietnam (Yuan, 2012: 1) Dzięki dwóm pierwszym członkowie Commonwealth utrzymali dominację wśród kandydatów do budowy Partnerstwa Transpacyficznego. Ostatnimi krajami które przystąpiły do negocjacji były Meksyk i Kanada. Między 2010 a 2013 rokiem odbyło się już 14 rund negocjacyjnych pomiędzy zainteresowanymi stronami. Ostatnia tura negocjacji Partnerstwa Transpacyficznego odbyła się między 4 a 13 marca 2013 roku w Singapurze, i według singapurskich przedstawicieli dynamika negocjacji znacznie się zwiększyła (Office of the United States Trade Representative) ${ }^{2}$. Pozwala to myśleć poważnie nad zakończeniem negocjacji już w 2013 roku.

Z 11 państw zainteresowanych uczestnictwem w tym wieloaspektowym porozumieniu handlowym, aż 6 stanowią członkowie Commonwealth. Jest to pierwsze multilateralne porozumienie preferencyjne, zgodne z duchem postanowień ostatnich rund negocjacyjnych Światowej Organizacji Handlu, w którym mogą znaleźć się państwa Commonwealth z Ameryki Północnej (Kanada), Oceanii (Australia i Nowa Zelandia) oraz Azji Południowo-Wschodniej (Singapur, Brunei, Malezja). Jak widać w powyższej krótkiej historii prac nad porozumieniem, od samego początku udział krajów Commonwealth był znaczący.

Dążenie do liberalizacji handlu zostało ustanowione jako jeden z celów Wspólnoty Narodów zawartych w Deklaracji Singapurskiej z 1971 roku (Singapore Declaration of Commonwealth Principles: 10). Szefowie rządów w konkluzji ze spotkania, które odbyło się 22 stycznia 1971 roku, przyznali iż „ich celem jest osiągnięcie możliwie najbardziej nieograniczonego przepływu światowego handlu na sprawiedliwych i równych dla wszystkich warunkach, biorąc pod uwagę specyficzne wymagania rozwijających się państw, a także zachęcenie do zainwestowania środków zarówno przez rządy jak i podmioty prywatne w rozwijających się państwach" (Singapore Declaration of Commonwealth Principles: 10). Ostatecznym celem organizacji jest zrównoważony rozwój i zwiększenie inwestycji w państwach stano-

\footnotetext{
1 Wen Jin Yuan, The Trans-Pacific Partnership and China's Corresponding Strategies, A Freeman Briefing Report, Centre for Strategic and International Studies, June 2012: 1.

2 The United States in the Trans-Pacific Partnership, Office of the United States Trade Representative.
} 
wiących Wspólnotę Narodów. Postępowanie krajów członkowskich Commonwealth $\mathrm{w}$ kontekście podjęcia negocjacji $\mathrm{w}$ sprawie rozszerzenia Partnerstwa Transpacyficznego jest więc zgodne z duchem Deklaracji Singapurskiej i długofalowymi celami organizacji. Uczestnictwo w tym wieloaspektowym porozumieniu może przyczynić się do zwiększenia wymiany handlowej pomiędzy państwami zrzeszonymi w organizacji.

Partnerstwo Transpacyficzne ma ambicje stać się „układem nowej jakości XXI wieku" (The Trans-Pacific Partnership Agreement), obejmując swoim zasięgiem nie tylko standardowy zakres porozumień o wolnym handlu ale też prawa własności intelektualnej, prawo zamówień publicznych, regulacje dotyczące pracy, środowiska czy też małych i średnich przedsiębiorstw. Głównymi założeniami dokumentu ma być liberalizacja handlu wzajemnego między państwami porozumienia, zwiększenie ich konkurencyjności na rynku globalnym, promocja nowoczesnych technologii: „zielonych”, zgodnych ze standardami ochrony klimatu, a także cyfrowymi (Office of the United States Trade Representative). Partnerstwo Transpacyficzne w dziedzinie ochrony środowiska ma prowadzić także do zwiększenia wysiłków na rzecz różnorodności biologicznej (The Trans-Pacific Partnership Agreement). Wielkość skumulowanych produktów krajowych brutto państw członkowskich TPP po przystąpieniu wszystkich zainteresowanych obecnie państw mogło by wynieść ponad 20 bilionów USD, wyprzedzając tym samym Unię Europejską (17 bln USD) i stając się największym blokiem handlowym na świecie. To także rynek konsumencki zamieszkiwany przez 650 milionów ludzi. Według analizy przeprowadzonej przez ekspertów z East-West Centre utworzenie TPP może przynieść korzyści światowej gospodarce w wysokości 104 mld USD do 2025 roku, 303 mld USD w przypadku integracji z innymi układami regionalnymi, oraz 862 mld USD, jeżeli ostatecznym celem stanie się wielostronna strefa wolnego handlu Azji i Pacyfiku (Free Trade Area of the Asia-Pacific FTAAP) (Petri, Plummer, Zhai, 2011: 4). Pierwszy pomysł stworzenia takiej strefy padł podczas spotkania APEC w 2006 roku w Hanoi.

Partnerstwo Transpacyficzne zostało poddane ogromnej krytyce ze strony mediów oraz antyglobalistów w państwach zainteresowanych przystąpieniem do negocjacji m.in. z powodu absolutnej dyskrecji, jaka charakteryzuje tury negocjacyjne. Przedstawiciele poszczególnych państw spotykają się za zamkniętymi drzwiami, co nadaje negocjacjom tajemniczy, nieprzewidywalny wydźwięk. Jedynymi upublicznionymi dokumentami w przypadku TPP były projekty poszczególnych zapisów, które wyciekły z amerykańskiego Departamentu Handlu. Jednym z tych dokumentów był projekt rozdziału dotyczącego przepływu inwestycji dający zagranicznym korporacjom m.in. prawo do zaskarżenia decyzji sądu krajowego do specjalnie ustanowionego trybunału, naruszając tym samym zdaniem niektó- 
rych zasadę suwerenności. W wielu krajach miały miejsce protesty mające przestrzec rządzących przed podejmowaniem decyzji o przystąpieniu do porozumienia bez wyrażenia opinii przez mieszkańców kraju.

Antyglobaliści oskarżają rządy państw zainteresowanych TPP, że działają na rzecz międzynarodowych korporacji prowadząc do jeszcze większego uzależnienia konsumentów od zagranicznej produkcji. Amerykańskie związki zawodowe, którym odmówiono wglądu do negocjowanego porozumienia alarmują, że porozumienie jest negocjowane m.in. przez 600 przedstawicieli korporacji z krajów zainteresowanych TPP, wśród amerykańskich wymieniane są Wal-Mart oraz Verizon. Do projektu dokumentu nie dopuszczeni zostali również członkowie Kongresu i Senatu, nawet zasiadający w komisjach zajmujących się handlem i mający za zadanie kontrolę administracji prezydenta Obamy. Amerykanie obawiają się wpływu porozumienia na rynek pracy, który poważnie ucierpiał na skutek kryzysu finansowego, oraz z powodu przenoszenia miejsc pracy do Azji Wschodniej i Południowej.

\section{Rola Australii w TPP}

Idea zwiększenia zaangażowania Australii w regionie Azji i Pacyfiku nie jest nową strategią polityki zagranicznej Canberry. W ostatnich latach sformułowana została przez byłego premiera Kevina Rudda, który w maju 2009 roku w trakcie spotkania Dialogu Shangri-la ponowił swoją propozycję utworzenia Asia Pacific Community, która została uprzednio zgłoszona w trakcie spotkania w Asia Society w Sydney (Thayer , 2009). Idea ta spotkała się jednak z ostrą krytyką zarówno w kraju jak i w regionie (He, 2009). Politycy sugerowali wzmocnienie dotychczasowych prób integracji regionalnej w postaci APEC oraz East Asian Summit. Problemem wskazywanym przez badaczy w przypadku Australii jest pewnego rodzaju dwoistość tożsamościowa. Z punktu widzenia stosunków ekonomicznych oraz położenia geograficznego Australia należy niewątpliwie do sfery oddziaływania Azji Wschodniej, jednak kulturowo znacznie bliżej jej do Zachodu. Kevin Rudd wyraził zainteresowanie wzięciem udziału w negocjacjach nad kształtem Partnerstwa Transpacyficznego już w listopadzie 2008 roku (Fergusson, Vaughn, 2010). Negocjacje w sprawie przystąpienia do TPP rozpoczęto w 2010 roku podczas tury w Melbourne. Premier Julia Gillard wyraziła zainteresowanie przystąpieniem zarówno do TPP, jak i przedstawianego jako konkurencyjnego RCEP.

Dla australijskiego rządu najważniejszymi przesłankami działającymi na korzyść przystąpienia do negocjacji w sprawie dołączenia do Partnerstwa Transpacyficznego są redukcja lub całkowita eliminacja barier 
w handlu i przepływie inwestycji w regionie, przy czym najważniejsze jest potencjalne zniesienie również barier pozataryfowych, takich jak: ograniczenia administracyjne, subsydia lub ograniczenia ilościowe. Dla Australii atrakcyjne jest uczestnictwo we wszystkich regionalnych strukturach ekonomicznych i politycznych, zgodnych z działalnością w ramach WTO. Ważny jest również dostęp australijskich eksporterów do zewnętrznych rynków, a także możliwość otwarcia regionu na inwestycje i przepływ kapitału z gospodarek rozwiniętych do rozwijających się.

Wśród potencjalnych zysków dla australijskich eksporterów wymienia się otwarcie peruwiańskiego rynku dla dostaw urządzeń górniczych oraz produktów spożywczych. Do tej pory Australia nie posiadała bilateralnej umowy handlowej z Peru. Perspektywiczna dla Australii jest również otwartość porozumienia na nowych członków: do tej pory ustalono jedynie konsensus że przystępujący do ugrupowania powinni posiadać dostęp do Pacyfiku. W dalszej perspektywie może to oznaczać rozszerzenie strefy wolnego handlu na pozostałe kraje rejonu Azji i Pacyfiku z którymi australijską gospodarkę łączą szerokie więzy. Do tej pory umowa o wolnym handlu łączy Australię jedynie z krajami ASEAN. W australijskim bilansie handlowym najważniejszą pozycje zajmują kraje członkowskie APEC - to właśnie z nimi odbywa się $71 \%$ handlu wzajemnego. Unia Europejska łącznie odpowiada za 13,5\% handlu z Australią. Wśród najważniejszych rynków eksportowych znajdują się Japonia, Stany Zjednoczone, Nowa Zelandia, Singapur i Tajlandia. Od 2005 roku Australię i USA łączy już strefa wolnego handlu (AUSFTA) jednak wynegocjowane porozumienie zawiera szereg odstępstw i ograniczeń, które mogą zostać wyeliminowane w przypadku wejścia w życie TPP.

\section{Rola Kanady w TPP}

Premier Stephen Harper wyraził zainteresowanie przystąpieniem do negocjacji w sprawie TPP podczas spotkania APEC w listopadzie 2011 roku w Honolulu (Dawson, 2012: 2). Wielu ekspertów krytykowało rząd, dając do zrozumienia, że przyłączenie się do procesu negocjacyjnego powinno nastąpić wcześniej. Wskazuje się przy tym, że możliwości takie pojawiały się od samego początku istnienia porozumienia P4 między czterema pionierami układu. W ten sposób kanadyjskie interesy mogłyby być lepiej zabezpieczone (Dawson, 2012: 2). Kanada przystąpiła ostatecznie do negocjacji w październiku 2012 roku. Otwarcie rynków krajów regionu Azji i Pacyfiku na kanadyjski eksport zdaniem rządu przyczyni się do zwiększenia aktywności handlowej co spowoduje przybycie nowych miejsc pracy oraz inwestycji. Rząd w Ottawie zwraca się w swojej polityce zagranicznej w stronę 
Azji i Pacyfiku, można powiedzieć, że podążając za trendami światowymi, mając na uwadze wzrost znaczenia państw azjatyckich na arenie międzynarodowej. Kanada chce za wszelką cenę uniezależnić się od eksportu na rynek amerykański, który wciąż pozostaje zdecydowanym liderem na liście. Stany Zjednoczone przeżywają jednak w ostatnim czasie własne kłopoty i chętniej wspierają lokalnych przedsiębiorców, dlatego też kluczowe dla rządu Stephena Harpera jest rozwijanie kanadyjskiej obecności na rynkach azjatyckich.

Od początku 2012 roku rząd kanadyjski rozpoczął proces konsultacji, zwracając się do przedstawicieli prowincji, terytoriów, sektora publicznego oraz prywatnego o przedstawienie swojego stanowiska w kwestii porozumienia. Problemem dla Kanady jest zniesienie barier w pewnych sektorach rolnictwa. Producenci nabiału i drobiu do tej pory byli chronieni przez politykę rządową, jednocześnie próbowano w ubiegłych latach zwiększyć eksport kanadyjskiego mięsa. Państwa członkowskie i negocjujące przystąpienie do Partnerstwa Transpacyficznego odpowiadają za 76\% ogólnego kanadyjskiego eksportu (Foreign Affairs and International Trade Canada). Zniesienie barier oraz otwarcie na inwestycje pozwoliło by na budowę jeszcze wyraźniejszej pozycji kanadyjskich przedsiębiorstw na rynkach regionu.

W jednym bloku współpracy gospodarczej Kanada ma szanse zwrócić się w stronę najszybciej rozwijających się państw Azji Wschodniej i Południowo-Wschodniej, utrzymując przy tym dotychczasowe zainteresowanie rynkami państw zrzeszonych w North American Free Trade Agreement (NAFTA) czyli Stanami Zjednoczonymi i Meksykiem. Wśród przeciwników porozumienia w Stanach Zjednoczonych funkcjonuje nazwa "NAFTA na sterydach", którą określane jest Porozumienie Transpacyficzne (Sierra Club). W tym sensie przez zaangażowanie po przystąpieniu do negocjacji w 2012 roku Meksyku i Kanady można stwierdzić, iż powstałe ugrupowanie będzie NAFTĄ z dodatkiem kilku państw basenu Pacyfiku.

\section{Przyszłość porozumienia TPP}

Poza negocjacjami w sprawie dołączenia do układu długo pozostawała Japonia, która wstępne zainteresowanie projektem wyraziła razem z Kanadą i Meksykiem już w 2010 roku. Problemem w przypadku Japonii był wysoki protekcjonizm stosowany przez japoński rząd w stosunku do krajowego rolnictwa. Silne lobby biznesowe mocno naciskało jednak od samego początku na rząd premiera Yoshihiko Nody, aby przyłączył się do rozmów nad kształtem porozumienia. Po zmianie gabinetu w Japonii, nowy premier Shinzo Abe (Partia Liberalno-Demokratyczna) aktywniej stara się 
włączyć trzecią gospodarkę świata w negocjacje. Piętnastego marca 2013 roku Shinzo Abe ogłosił, że jego kraj przystąpi do oficjalnych negocjacji nad porozumieniem ale oczekuje on od prezydenta Stanów Zjednoczonych Baracka Obamy ustępstw w zakresie ochrony japońskiego rynku. Wśród kolejnych kandydatów potencjalnie zainteresowanych uczestnictwem w TPP wymienia się Koreę Południową, Filipiny oraz Tajwan.

Z pewnością dołączenie tych państw do ugrupowania jeszcze wzmocniłoby korzyści dla Australii, Nowej Zelandii czy Kanady. Trzy ważne kraje Wspólnoty Narodów odgrywają obecnie w Partnerstwie Transpacyficznym kluczowe role i mogą dzięki uczestnictwie w porozumieniu znacznie umocnić swoje znacznie w rejonie Azji i Pacyfiku. Pozostałe mniejsze kraje Commonwealthu - Brunei, Singapur i Malezja uczestniczą od pewnego czasu w liberalizacji handlu w regionie pod szyldem ASEAN (Stowarzyszenie Państw Azji Południowo-Wschodniej). Dzięki obecności w TPP większych gospodarek Wspólnoty Narodów możliwe będzie nawiązanie lepszych relacji handlowych, bazując na wspólnym dziedzictwie oraz wypracowanych standardach w ramach Commonwealth. Po zwycięstwie Baracka Obamy w wyborach prezydenckich w Stanach Zjednoczonych bardziej prawdopodobne jest przyspieszenie prac nad ostatecznym dokumentem. Krytycy zarzucają w związku z tym USA promowanie układu TPP jako sposobu na powstrzymywanie rosnących chińskich wpływów ekonomicznych na kontynencie (Yuan, 2012: 3). Stany Zjednoczone chcą odgrywać większą rolę w regionie Azji i Pacyfiku, nie tylko utrzymując znaczne siły militarne zdolne do projekcji swojej potęgi, ale także poprzez uniezależnienie gospodarek regionu od chińskich inwestycji i handlu wzajemnego.

Partnerstwo Transpacyficzne jest w podobnym kontekście postrzegane również przez niektórych komentatorów jako przeciwwaga do innej propozycji, za którą stoją głównie Chiny i Japonia. Regional Comprehensive Economic Partnership (RCEP) miałoby obejmować 16 państw regionu Azji i Pacyfiku: 10 członków ASEAN, Chiny, Japonię, Koreę Południową a także Indie, Australię i Nową Zelandie. Taki blok stanowiłby regionalną strefę wolnego handlu o potencjale porównywalnym do Unii Europejskiej. W wymiarze demograficznym tworzony blok gospodarczy zamieszkiwałoby 3 miliardy osób, natomiast łączny PKB osiągnąłby poziom 17 bln USD. Twórcy ugrupowania nie wykluczają jednak możliwości przyjęcia w swoje szeregi kolejnych państw w przypadku powodzenia integracji; nie jest wykluczone również uczestnictwo w równolegle tworzonych inicjatywach. Taki blok gospodarczy z pewnością miałby szanse stać się w przyszłości organizacją najbardziej znaczącą dla światowego handlu, wykluczając dotychczasowe potęgi takie jak Stany Zjednoczone czy państwa Europy Zachodniej. 
Prace nad RCEP rozpoczęto podczas 19. Szczytu ASEAN w listopadzie 2011 roku na Bali w Indonezji, która sprawowała w tym czasie przewodnictwo w ASEAN. W pracach nad porozumieniem starano się połączyć ze sobą dwie koncepcje forsowane przez Chiny oraz Japonię. East Asia Free Trade Agreement - projekt strefy wolnego handlu obejmujący ASEAN, Chiny, Koreę Południową i Japonię wspierany przez Pekin, oraz Comprehensive Economic Partnership in East Asia, który rozszerzał chiński projekt o państwa Oceanii - Australię i Nową Zelandię, także Indie. Negocjacje weszły w następną fazę podczas 21. Szczytu ASEAN, który odbył się w stolicy Kambodży Phnom Penh między 19 a 21 listopada 2012 (Bangkok Post, 2012). Finalizacja rozmów między stronami porozumienia jest planowana na 2015 rok. W pracach nad RCEP biorą udział państwa Commonwealth, jednak ich rola jest zdecydowanie ograniczona.

Wśród państw zrzeszonych we Wspólnocie Narodów panuje przekonanie o korzyściach płynących z liberalizacji światowych stosunków ekonomicznych, ugruntowane w Deklaracji Singapurskiej z 1971 roku. Następna runda negocjacyjna nad porozumieniem Partnerstwa Transpacyficznego została zaplanowana na maj 2013 roku i odbędzie się w stolicy Peru - Limie (Fergusson, 2013). Celem dla przywódców jest podpisanie porozumienia trakcie zaplanowanego na październik 2013 roku szczytu APEC w Indonezji.

Rola państw członkowskich Commonwealth w trakcie prac nad Partnerstwem Transpacyficznym od samego początku była znacząca. Przenoszenie się centrum światowych stosunków ekonomicznych w stronę basenu Pacyfiku jest symbolizowane przez projekty polityczne mające miejsce w tym regionie. TPP może być postrzegana jako środek amerykańsko-chińskiej rywalizacji, jednak waga porozumienia dla mniejszych gospodarek po obu stronach oceanu jest bardzo duża.

\section{Bibliografia}

Dawson, Laura. Can Canada Join the Trans-Pacific Partnership? Why Just Wanting it Is Not Enough, C.D. Howe Institute, Commentary No. 340, February 2012.

Fergusson Ian F. Bruce Vaughn. The Trans-Pacific Partnership Agreement. Congressional Research Service, June 25, 2010.

Fergusson, Ian F. et al. The Trans-Pacific Partnership Negotiations and Issues for Congress, Congressional Research Service, March 19, 2013.

James, Sallie. Is the Trans-Pacific Partnership Worth the Fuss? Center for Trade Policy Studies, Free Trade Bulletin No. 40, 15 March 2010.

Petri, P., M. Plummer, Fan Zhai. "The Trans-Pacific Partnership and Asia-Pacific Integration: A Quantitative Assessment". East-West Center Working Papers, Economic Series No. 119, October 2011. 
The Trans-Pacific Partnership Agreement: Challenges and Potential. Joint Hearing before the Subcommittiee on Terrorism, Nonproliferation, and Trade, Subcommittiee on Asia and the Pacific of the Committee on Foreign Affairs House of Representatives 112th Congress, 17 May, 2012, Serial No. 112-144

Yuan, Wen Jin. The Trans-Pacific Partnership and China's Corresponding Strategies. A Freeman Briefing Report. Centre for Strategic and International Studies, June 2012.

\section{The Role of Commonwealth Members in the Building of Trans Pacific Partnership}

Summary

The Trans Pacific Partnership (TPP) can play a major role in a constantly changing world of economic interdependencies because of the potential and capabilities of the member countries. The size and high growth rates of several economies from Pacific Asia, North and South America enhance integration efforts undertaken at both the political and economic levels. This article describes the role of Commonwealth members in the building of Trans Pacific Partnership. From the very beginning of the integration, Commonwealth member states were in the majority and had a decisive influence on the actions taken. The desire to increase cooperation in the field of economic relations, and the liberalization of world trade were also the basis for creation of Commonwealth, as it was stated in The Singapore Declaration of Commonwealth Principles, which defined the goals of the organization. The role of Canada and Australia was particularly analyzed because of their size and potential. 